\title{
The Use of Social Media Platforms as Awareness Creation Tools for the Hepatitis B Virus in Lagos State
}

\author{
Nsikan Senam ${ }^{1}$, Charles Okonji ${ }^{2}$ \\ ${ }^{1}$ Department of Communication Arts, University of Uyo, Uyo, Nigeria \\ ${ }^{2}$ Department of Mass Communication, Anchor University, Lagos, Nigeria
}

\begin{abstract}
The social media have constituted a fundamental platform for the dissemination of vital information for use by members of the society. This makes it necessary to expect that some vital information on health issues, such as Hepatitis B Virus, can be transmitted to people through social media platforms, despite some outstanding dysfunctions of the social media. This study examines the extent to which social media platforms are used to the tools for creating awareness on Hepatitis B Virus in Lagos, Nigeria. The population of the study was 14,368,332 which was the projected population of Lagos State. The sample size was 400 selected through the multi-stage sampling method. The questionnaire was the instrument for data gathering. Findings of the study revealed that majority of Lagos State residents were exposed to social media platform. Also messages on Hepatitis B Virus were transmitted through the various social media to residents of Lagos State. It was therefore recommended among other things that operator and managers of health facilities in Lagos State should make use of the social media platforms as part of the potent channels of transmitting information on health issues such as Hepatitis B Virus.
\end{abstract}

Keywords: Awareness, Facebook, Hepatitis B Virus, Instagram, Lagos, social media, WhatsApp

\section{INTRODUCTION}

$\mathrm{H}$ epatitis, a viral infection, is known to affect the liver, a strategic organ in the body. The liver produces bile for digestion, filters toxins from the body, breakdowns food, and excretes bilirubin, among other functions. Mancinelli et al (2020) identified five types of viral hepatitis, which include hepatitis A, B, C, D, and E. According to these experts, Hepatitis A virus (HVA) and Hepatitis E virus (HEV) are transmitted through the consumption of food or water, which is contaminated by feces from an infected person, while Hepatitis B virus (HBV), Hepatitis C virus (HCV) and Hepatitis D virus (HDV) are contracted through contact with infectious body fluids like blood, vaginal secretions, or semen.

In Nigeria, some medical experts have expressed much concern at the rate that $\mathrm{HBV}$ is spreading without the Federal Government making serious efforts to address it. As they claimed, HBV is spreading astronomically. Some asserted that $\mathrm{HBV}$ is about 50 to 100 times deadlier than Human Immunodeficiency Virus (HIV), an infection that destroys white blood cells, called CD4 cells, and weakens the body's immune system. Yet, only a few people in the country are aware of this HBV, which is classified as one of the most severe infectious diseases and can lead to high morbidity and mortality.

At an early stage, known as the acute stage, the HBV, according to some medical experts, can only be a mild illness that might last for a few weeks. Within this period, it can cause fever, fatigue, loss of appetite, nausea, vomiting, or jaundice. With jaundice, the patient will experience yellow skin or eyes. Sometimes, the patient may have dark urine, clay-colored bowel movements. The patient with acute HBV infection may have pain in the muscles, joints, and stomach.

For chronic HBV infection, which can cause serious and lifelong illness, the patient may have liver damage, better known as cirrhosis, or liver cancer. It may eventually lead to the patient's death. Some medical experts, however, revealed that the chronically-infected people might not feel or look sick themselves. Yet, they have high potency of spreading the virus to other people. As these medical experts pointed out, HBV can be transmitted through exposure to infectious blood or body fluids. Among the forms of transmission include sexual contact and blood transfusions. Others include re-use of contaminated needles or syringes and vertical transmission from Mother to Child (MTC) at childbirth.

Having unprotected sex with an infected person can cause the spread of the virus can through the blood, semen, or vaginal secretions. Through the sharing of contaminated needles or syringes, the virus can also put a person at high risk, while an infected pregnant woman can pass the HBV to her baby during childbirth, except the newborn is vaccinated within 24 hours of birth. The Nigerian government, over the years, had spent a huge amount of money on the healthcare system without efforts to create awareness of the health implication of HBV. The Federal Government's focus has been on AID/HIV and other diseases. About 67 percent of children got the BCG vaccine against tuberculosis. In 2018, about 55 percent of children received polio vaccination, while 65 percent received vaccination against diphtheria, Tetanus, Pertussis, Haemophilus Influenza, and Tetanus.

Though the Nigerian government's expenditure on health, in 2017, was 3.8 percent of the Gross Domestic Product (GDP), the health expenditure, in 2019, increased significantly, 
standing at N1.191 trillion. For 2021, the government is projecting an expenditure of N1.478 trillion, while the private sector's forecast on health is put at N4.284 billion by 2021. With this planned huge investment for the health sector, there should be efforts to create awareness of HBV and vaccination programme. As against traditional media, the use of social media has taken the centre stage in the country, which should make the Federal Government to give the platforms serious consideration in the creation of awareness for HBV. Olusola (2018) noted that with social media, people could easily connect with their families and friends, and share useful information.

Apart from chatting and social networking, which can help others keep in touch and find new relationships, Olusola (2018) pointed out that social media could contribute to the education of people and exposure to meaningful programmes. Social channels, according to him, could be used for campaigns and raise awareness. He added that Facebook, WhatsApp, Twitter, and other online platforms could have merits of unlimited access, and cheaper method of communication. In a recent research, which was conducted by NOIPolls (2019) on social media platforms utilisation in Nigeria, 51\% preferred WhatsApp because of its speed, simplicity, and privacy, while $45 \%$ favoured Facebook because of its connectivity and wider reach. The research also revealed that 39.6 million Nigerians, representing $20 \%$ of the nation's population, have Twitter accounts.

\section{Statement of the Problem}

Hepatitis B Virus (HBV) is a deadly infection which has cause a lot of deaths in the whole world over time. The deadly nature of HBV has therefore become an issue of concern among people, especially medical professionals. The existence of other kinds of viral diseases such as HIV/AIDS, Corona Virus Disease (COVID-19) etc seems to have taken people's mind away from the danger and deaths caused by HBV in Nigeria.

Over the years, many individuals, groups and organisations have been carrying out many different communication activities aimed at enlightening the citizenry on the deadly nature of the HBV and how to curtail its spread. The publicity activities have been carried out on the various media of human communication through various communication messages and strategies, such as interpersonal communication, public service announcements on the mass media, media campaigns, social advertisements etc. With the emergence of the information and Communication Technologies (ICTs), the dissemination of information on HBV has not only become easier and speedier, but messages are readily available to greater number of people than before.

One of the strategies of disseminating information on the deadly virus, Hepatitis B is the social media marketing in which messages are disseminated or transmitted to the people through the various social media platform. In Ikeja, Lagos State, incidents of HBV seems to be in the increase despite social media marketing strategy on the social media platforms which are readily available to a greater percentage of Ikeja residents thereby making it seem as if residents of Ikeja are not exposed to social media marketing strategies on HBV. The concern then is whether Ikeja residents are not exposed to social media messages about HBV. In other words, are the residents of Ikeja aware that $\mathrm{HBV}$ is more deadly than HIV/AIDS? Again, what is the extent of Ikeja residents' awareness on the various means of transmission HBV?

\section{Research Questions}

The following research questions were set out to serve as a guide to the study:

1. To what extent are the residents of Lagos State in Nigeria exposed to social media platform?

2. To what extent are residents of Ikeja exposed to social media marketing messages on Hepatitis B Virus (HBV)?

3. Through what social media platform are residents of Ikeja exposed to messages on HBV?

4. To what extent are residents of Ikeja aware that HBV is more deadly than the much dreaded HIV/AIDS?

5. Are residents of Ikeja aware of the various modes of transmission of HBV?

\section{LITERATURE REVIEW}

World Health Organisation (WHO), in its 2019 Report on Hepatitis B, had informed that approximately one-third of the world's population got infected with HBV. Out of this figure, according to the WHO, about 5\% usually become chronic carriers. One-quarter of the chronic carriers could develop into serious liver diseases such as chronic hepatitis, cirrhosis, and hepatic carcinoma.

The WHO's report further revealed that every year, 780,000 HBV-related deaths occurred globally, a position that Jefferies et al (2018) equally shared, noting that with the high risk of $\mathrm{HBV}$, if the virus developed into a chronic infection, it could result to serious complications. While pointing out that $\mathrm{HBV}$ is inversely related to the age of infection, Jefferies et al (2018) stated that the virus, if the infection occurs prenatally, has about $90 \%$ risk of developing into chronic infection with subsequent complications.

Jefferies et al (2018) also revealed that sub-Saharan Africa and East Asian countries have predominantly transmitted HBV through perinatal or horizontal route, while Schweitzer (2015), cited in Jefferies et al (2018), stated that for developed countries, young adults mostly contract the HBV infections, but this is via drug injection and sexual intercourse.

Musa et al (2015), who noted the high risk of HBV, especially in Nigeria, declared that is hyperendemic, causing one of the major global liver disease morbidity and mortality. According to these researchers, HBV accounted for over 360 million cases of chronic hepatitis and 620,000 deaths per year. In SubSahara Africa (SSA), more than $8 \%$ of the population is infected. 
Perz et al (2006), cited in Musa et al (2015), attributed 44\% of cirrhotic liver disease and $47 \%$ of hepatocellular carcinoma cases in SSA to HBV. Despite the high health hazard of the $\mathrm{HBV}$, as it is reckoned to be about 100 times deadlier than HIV, the Nigerian government has not taken any serious efforts to tackle it, unlike health programmes on HIIV and polio.

At the moment, there is a highly effective and inexpensive recombinant DNA vaccine for HBV. Globally, according to Musa et al (2015), the vaccine for hepatitis B became available since 1982, but it debuted in Nigeria in 1995. Apart from Lagos State Government, which recently made the vaccination compulsory for children at birth, the Federal Government has not made any concerted efforts embark on vaccination programmes.

In developed countries, governments fund the vaccination to combat this virus, but in Nigeria, as GAVI Alliance (2014) noted, while citing the United Nations Children's Fund (UNICEF) and the WHO's reports, the Nigerian government's funding for the HBV's vaccine provision has been quite insignificant. In 2013 , only $41 \%$ of Nigerians got vaccinated against HBV.

Ola et al (2002), cited in Musa et al (2015), bemoaned the high risk of Nigerians to HBV, equally hinging it to low vaccination rates and exposure of about $75 \%$ of the population to the virus. Emechebe et al (2014) disclosed that previous reports of HBV in Nigeria estimated the prevalence risk of the virus to the Nigerian population at between $10 \%$ and $15 \%$, but now the figure has risen to an imaginable level.

The pathetic situation is that the Nigerian youths engaged in high unprotected sex, which exposes them to the risk of contracting the virus. Many of the Nigerian married men and women are equal in the league of avaricious promiscuity. Apart from these categories of people, surgeons and blood donors have also been found to be among those with high HBV prevalence in Nigeria. Belo (2000), as cited in Musa et al (2015), put the virus prevalence among surgeons at $25.7 \%$, while Bada (1996), also cited in Musa et al (2015), posited that voluntary blood donors are about $23.4 \%$ and Sadoh and Sadoh (2013), equally cited in Musa et al (2015), stated that infants infection of $\mathrm{HBV}$ is at $16.3 \%$.

In 2010, the WHO Assembly adopted resolution 63.18, which recognized viral hepatitis as a global health problem. The world health body developed a four-prong strategy to address the challenge. Parts of the WHO's efforts were to raise awareness of the virus and mobilise resources, which can be used towards policy formulation, prevention of transmission of $\mathrm{HBV}$, screening of the virus, and its treatment. Following this agenda, 180 countries included Hepatitis B vaccination as part of their routine vaccination schedule, while the worldwide coverage approached $80 \%$ in 2011 . With the WHO's effort, Pries (2008) pointed out that what remained to be addressed is to reduce the disparities of the virus infection between developed and developing countries.
Also in March 2015, WHO, while launching its guidelines to eliminate HBV, recommended the promotion of the use of simple, non-invasive diagnostic tests for the stage of liver disease and the treatment of the virus. In May 2016, the WHO initiated a strategy that could align its combative efforts against HBV with the Sustainable Development Goals. The strategy aimed at reducing HBV infections by $90 \%$ and its deaths by $65 \%$ by 2030 .

Yet, the Nigerian government has not made significant efforts to stop the spread of the virus in the country. Despite the WHO's supports for countries, including Nigeria, to tackle the virus, less than one percent of the population, at the moment, is aware of the HBV. This has become a serious concern. Now, everybody glues to social media, putting serious consideration for the use of online and social media to raise awareness of this virus in Nigeria.

Before the use of social media as a means of dissemination of information and creation of awareness of products and services, mainstream media like newspapers, magazines, radio, and televisions were used. Even then, a limited number of people could only be exposed to those products and services because of the non-availability of the media to some of the readers and viewers. As the internet and mobile phones emerged, social media, which are interactive computermediated technologies, took over the airwave as people could create messages at the comfort of their rooms for millions of people within a few seconds by mere clicking of some buttons.

Ortiz-Ospina (2019) stated that social media, with its rapid and vast adoption of modern technologxzies, have changed the world. With the world's population of 7.7 billion people, more than 3.6 billion are hooked up to social media. Among the most popular social media websites, today, are Facebook, TikTok, WeChat, Instagram, QZone, Weibo, Twitter, Tumblr, Baidu Tieba, and LinkedIn. Others include WhatsApp, YouTube, VK, Telegram, QQ, Quora, LINE, Reddit, Snapchat, Viber, Reddit, Discord, and Pinterest.

According to Ortiz-Ospina (2019), MySpace became the first social media site to achieve a milestone of a million monthly active users in 2004. TikTok, which was launched in September 2016, also recorded a half-billion users by mid2018. Between 2016 and 2016, TikTok gained an average of 20 million new users every month.

Statista (2020) stated that, as in April 2020, Facebook had recorded 2.5 billion active users, while YouTube and WhatsApp had 2.0 billion each. Others include Facebook Messenger with 1.3 billion; WeChat, 1.165 billion; Instagram, 1.0 billion; TikTok, 800 million; QQ, 731 million; Qzone, 517 million; Sina Weibo, 516 million; Reddit, 430 million; Kuaishou, 400 million; Snapchat, 398 million; Twitter, 386 million; Pinterest, 366 million; Baidu Tieba, 320 million; LinkedIn, 310 million; Viber, 260 million; and Discord, 250 million. 
Social media marketing, because of the attraction to social media platforms and websites, has become an effective instrument to promote a product and service. Chaffey and Ellis-Chadwick (2012) stated that different organisations currently use social media to advertise their products and services. Aside from a large number of people seeing the adverts, social media could be used to target specific audiences to create awareness of the policies and diseases, among others.

Shu-Chuan (2011) pointed out that social media could be used as a feedback mechanism. As they get the message, social media users could respond to the message immediately. The users could not only indicate their likes, but they could also share the information with their friends and relatives, or comment on it.

Olufemi (2016) informed that in 2016, Nigeria had 86.219 million internet users. Before that, precisely in 2013, 7.1 million Nigerians were active on Facebook and 1.8 million on Twitter. In 2014, Instagram users added to the figure with 3.21 million.

Olufemi (2016) highlighted why many organizations, governments, and individuals preferred the use of social media marketing for their products and services. Firstly, social media marketing helps to expose their brand to the target audience. As post and tell people about their brand, it would become known with high value. Secondly, social media help to effectively target audience. Organisations normally go to the social media platform where they could locate their audience. Thirdly, through this approach, they could meet new customers, as a social media platform would create such an avenue to meet people. Fourthly, apart from helping to reach a large number of people with minimum cost, social media help drive traffic to the website and enhance express feedback.

Evans and Mckee (2010), cited in Nyekwere et al (2013), stated that social media have made users become active participants. According to Chaney (2009), companies and other organisations appreciate the significant embark of social media, as their customers are no longer passive consumers of their products and services.

Social media, Ekwueme (2018) pointed out, have assisted a lot of people to express their opinions, needs, and values. Organisations leverage the platforms to not only recognize the needs of their customers but also seek new ways to meet them. They use online platforms to communicate information on price, product, and place their target audience.

Gummesson (2002), cited in Odhiambo (2012), added that marketers, through frequent communication, can establish and sustain relationships with their customers. Janal (1998), cited in Odhiambo (2012), stressed that marketers, through some social network constructs, have created their communities. Therefore, information flow within the communities could strengthen the relationship.

Social media helps to achieve a wider reach. Organisations could reach an array of audiences, which could reside locally, regionally, nationally, or internationally. As McLuhanian said that the world has become a global village, social media have helped organizations to reach their audience anywhere and everywhere.

\section{Theoretical Framework}

This study was founded on the framework of the social cognitive theory, which was postulated Miller, N. E. and Dollard, J. (1941). The theory is relevant to health communication and hinges on how people acquire and maintain certain behaviours through information acquisition. According to the theory, changes in human behaviour are influenced by factors: environment, people and behaviour. The combined effect of the cognitive and mental representations of the environment coupled effects, moves or activities of people in the environment as well as the behavioural patterns of other people greatly influences the behaviour of another person called the learner. Generally these factors of behavioural pattern are products of social factors. These social factors influence a person's behaviour through the persons cognitive efforts such as observation, reinforcement, imitation etc. thus the name social cognitive theory.

Social Cognitive Theory is mostly concerned with behavioural effects. People are motivated to emulate or imitate other people's behaviour or have a change of attitude based on the learners' yearnings and aspirations as well as what they fancy or how much they appreciate the act of the model or their activities. The social cognitive theory also emphasises on the importance of a person's (an observer's) ability to imitate a particular behaviour of other persons (models) to fit the surrounding social circumstances (Anaeto, Onabajo \& Osifeso, 2008). Given the above analyses, the social cognitive theory is useful in every aspect of communication practice that intends to effect some changes in the behaviour or attitude of the audience.

In any area that the theory may be applied, self-control is indispensable. In order to make meaning out of any social behaviour or in a social environment, a person has to exercise a commendable degree of self-control. For good behavioural changes to take place there must be personal regulation of goal-directed behaviour or performance. This provides opportunities for self-monitoring, goal-setting, problemsolving and self-reward. The ultimate outcome of self-control is desired behavioural change as opposed to unintended behavioural change. The social cognitive theory is particularly relevant to this study in the sense that both theory and the study have a lot to do with attitudinal change. The study relates to the concept of knowledge, attitude and change as it set out to examine how the respondents' attitude are affected when they receive messages on Hepatitis B Virus (HBV) on the social media. The Social media have come to play greater roles, where individuals and corporate organisations chat and send twit to people in multiple numbers to create awareness on issues, ideas, projects, products, services, and programmes, among others. 


\section{RESEARCH METHODOLOGY}

The survey was the research method adopted in this study since this study hinged on people's opinions and attitudes. As the population of a research is the entire numerical strength of the entity within which all the subjects of the study are found (Senam, 2020), the population of all the users of any of the social media platforms in Lagos State was used for this study.

However, there is no recorded statistics of the number of Lagos residents, who use any of the social media platforms, but the total number of Lagos residents is known. According to World Population Review (2020), the projected population of Lagos is 14,368,332 and, therefore, constituted the working population of the study.

When the population size of the study is too large for complete census, the idea of sampling becomes inevitable. For Osuala (2007), sampling is any portion of the population as representative of the population of the study. Since the population was definite, the Yamane (1967) formula was used to determine the sample size. According to his formula, when a Confidence Level is $95 \%$, the Precision Levels or Significance is 0.05 .

Therefore, the researchers adopted the Taro Yamane statistical formula to determine the sample size for the study. The formula is: $\mathrm{n}=\frac{N}{1+N(e)^{2}}$ where $\mathrm{n}=$ the sample size, $\mathrm{N}=$ the finite population, $\mathrm{e}=$ error unit or margin error (the level of significance), which is usually 0.05 , and $1=$ unit or a constant figure. Using this formula, the calculation is done below:

$n=\frac{N}{1+N(e)^{2}}$

$$
\begin{gathered}
n=\frac{14,368,332}{1+14,368,332(0.05)^{2}} \\
n=\frac{14,368,332}{1+14,368,332(0.0025)} \\
n=\frac{14,368,332}{1+35920.83} \\
n=\frac{14,368,332}{35921.83}
\end{gathered}
$$$$
n=399.98
$$

$$
n=400
$$

From this above calculation, using Taro Yamane formula, the sample size for this study was 400 from the total population of $14,368,332$.

\section{DATA PRESENTATION AND ANALYSIS}

The questionnaire was the instrument for data collection. The data gathered were presented in charts and graphs and computed in simple percentages. The data are presented as follows:
1. What is your gender?
401 responses

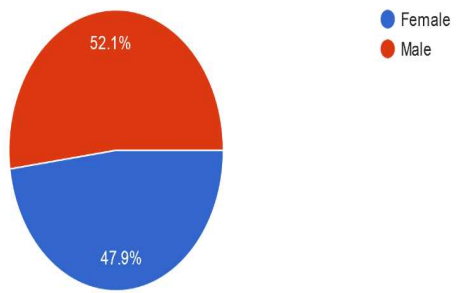

2 On which of these social media platforms are you? (Please tick as many as applicable) 402 responses

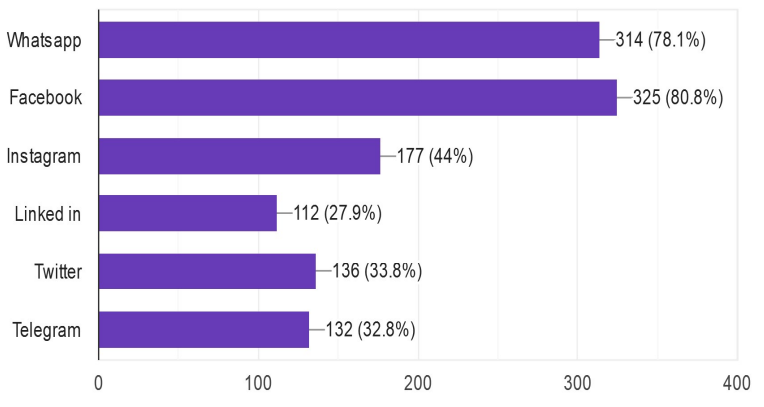

3. Do you access messages about Hepatitis B Virus on social media? 398 responses

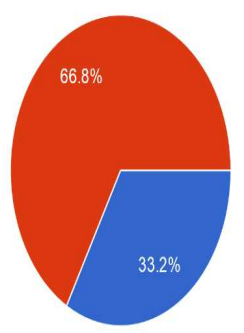

Yes

No

4. If yes in No. 3 above, how often?

182 responses

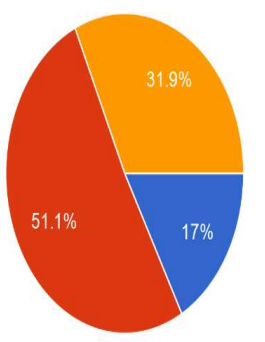

Very often

Occasionally

- Very sparingly 
5. Through which social media platforms do you receive messages on Hepatitis B Virus on social media? (Please tick as many as applicable)

249 responses

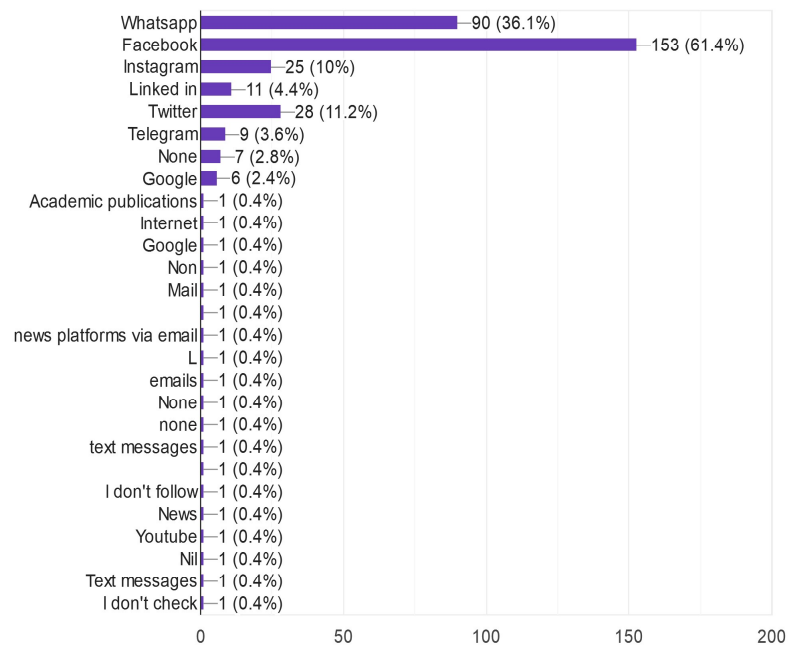

6. Are you aware that Hepatitis B Virus is a deadly disease?

392 responses

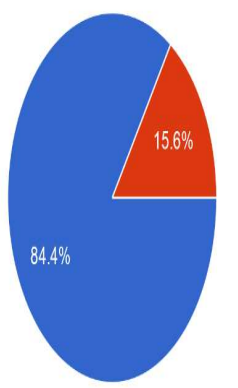

$O$ Yes

N No

7. Is Hepatitis B Virus more deadly than HIVIAIDS?

377 responses
8. If yes in No. 7 above, to what extent?

310 responses

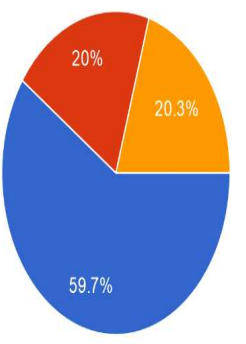

Verywell

Notmuch

Not even certain

9. What are the modes of transmission of Hepatitis B Virus? (please tick as many as applicable) 335 responses

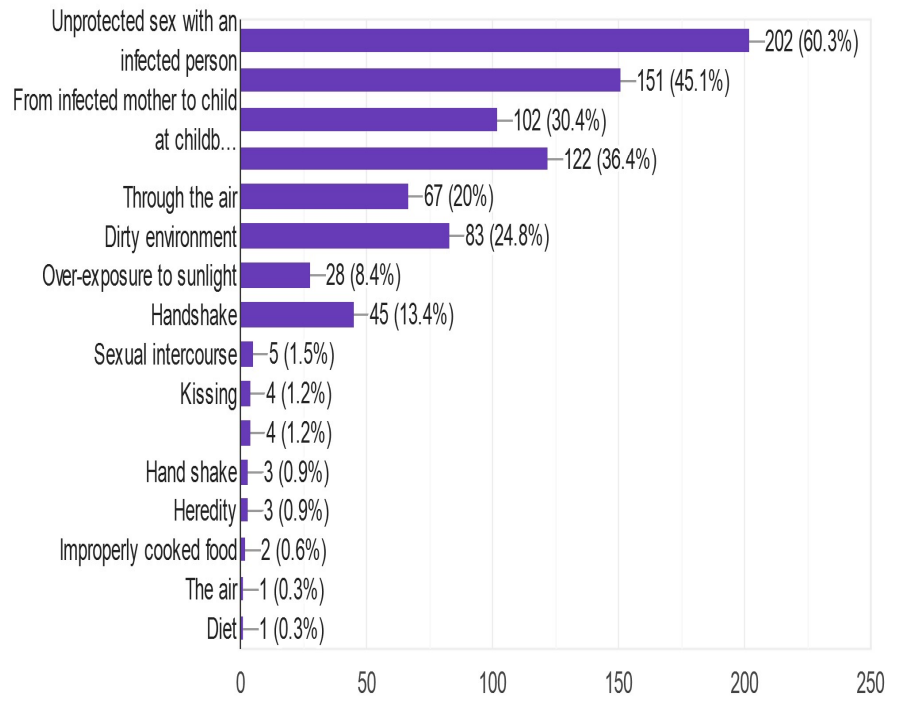

10. Do you have challenges accessing messages on Hepatitis B Virus through social media? 370 responses

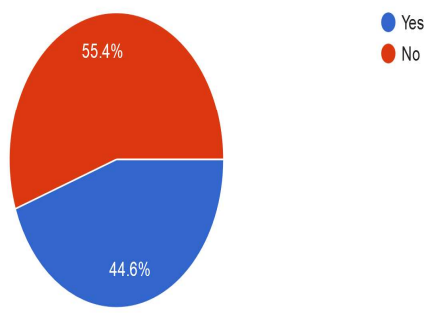




\section{If yes in No. 10 above, what are the challenges? (Please tick as many as applicable) 231 responses}

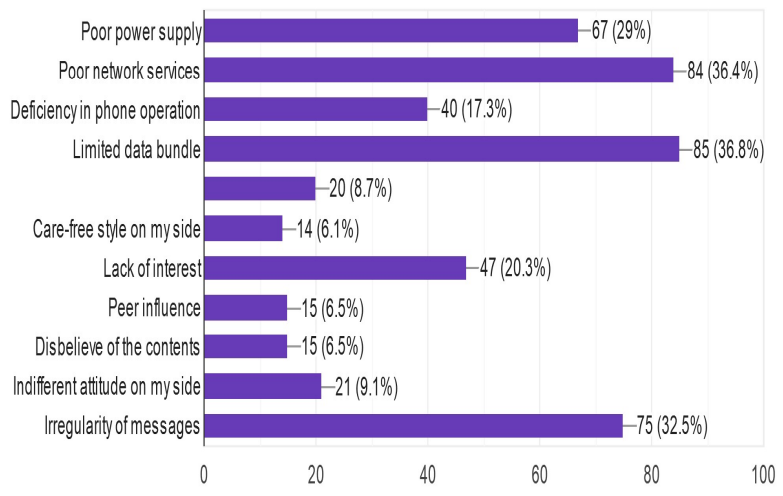

\section{Hepatitis B Virus or HIVIAIDS, which one do you think kills faster?} 383 responses

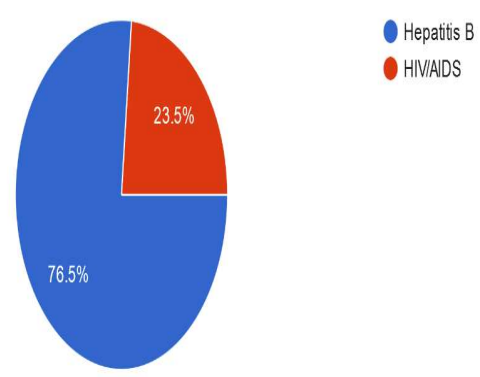

\section{Hepatitis B Virus or HIVIAIDS, which one are you more afraid of?} 375 responses

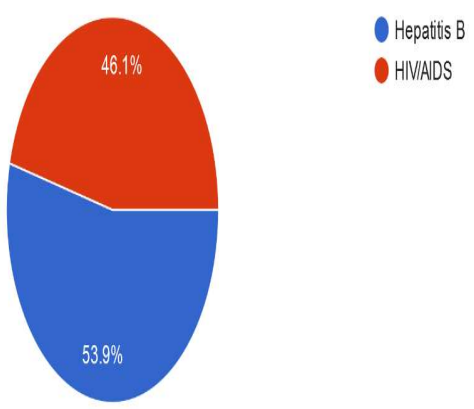

\section{Do you usually take conscious steps to prevent yourself from contracting Hepatitis B Virus? 380 responses}

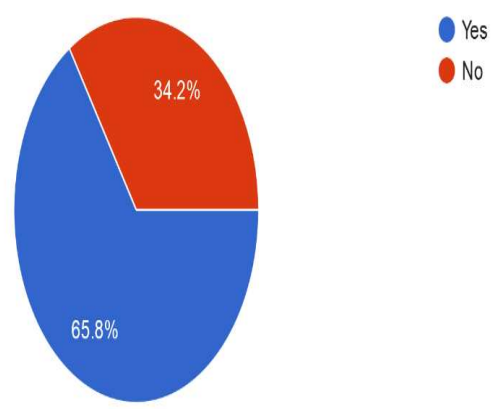

\section{Discussion of Findings}

From the data analysis, which has $52.4 \%$ of males and $47.6 \%$ of females, a large number of residents in Lagos State disclosed that they have social media platforms. Precisely, $78 \%$ of the respondents, representing 11.20 million of the total population of 14.4 million of Lagos State population, disclosed that they have a WhatsApp platform. The research equally revealed that $80.8 \%$ of the population, which is 11.60 million, is on the Facebook platform, while $44 \%$ is on Instagram; $28 \%$ on Linked-in; $33.8 \%$ on Twitter, and $32.8 \%$ on Telegram.

With a large number of the population being on social media platforms, these researchers felt that HBV messages should have been adequately and properly disseminated among the residents of Lagos State through WhatsApp, Facebook, Instagram, Linked-in, Twitter, and Telegram platforms. Unfortunately, the reverse is the case as both the Federal Government and Lagos State Government have not utilised the social media platform, as effective channels of creating awareness on the effects of HBV in the state.

Particularly, $66.7 \%$ of the population, which represented 9.58 million, pointed out that they had never received any message on HBV through any of their social media platforms. Only $33.3 \%$ stated that they had received one message or the other on HBV through their social media platforms.

Out of this population of the residents that received messages on HBV, which composed of 4.78 million, only $17.1 \%$ of them disclosed that they received the messages on HBV "very often," while $82.9 \%$ of the population, representing 11.9 million, said that they occasionally or very sparingly received HBV messages.

Some of the residents, who disclosed that they had little information about the virus, according to the findings in this research, got the knowledge on HBV through other media platforms. Among those that knew about HBV, $84.4 \%$ said that the information they got indicated that HBV is a deadly 
virus, while $15.6 \%$ said they were not aware that $\mathrm{HBV}$ is a deadly virus.

Even among those who knew the deadly nature of HBV and its transmission, $27.1 \%$ of the population said the virus is not deadly to the extent as to create apprehension in people's minds, though $72.9 \%$ of the residents still believed that the virus is "very deadly."

Some of them admitted that HBV can be caused by unprotected sex with an infected person, sharing of contaminated needles or syringe, from infected mother to child at childbirth, sharing of contaminated cutlery, and blood transfusions. Among this category of the residents, only a few said they had taken vaccine and hepatitis B immune globulin. Others said they take precautions by ensuring that they do not share any sharp object with anyone, careful of not being pierced with rotten metals or iron, avoid having unprotected sex.

Unfortunately, some of the residents, who noted the existence of the virus, did not know the actual causes of HBV. They guessed that it could be caused by the air they breathe, dirty environment, over-exposure to sunlight, handshake, kissing, heredity, and improperly cooked food. Their only precautions include avoiding eating unwashed fruits, not using dirty toilets, staying away from a polluted environment, and avoid kissing, among others. Their ignorance of the deadly nature, causes and prevention indicated that there should be more awareness programme of $\mathrm{HBV}$, especially through the social media since more than $80.8 \%$ of the population is on social media platforms.

\section{CONCLUSION}

This research revealed that the residents of Lagos State in Nigeria are adequately on social media platforms, which can be used to create awareness of HBV. Only a few of the residents are aware that HBV is very deadly and its transmission modes. Majority of them are still wallowing in ignorance about the virus. Since more than $80.8 \%$ of the population admitted that they have social media platforms, it becomes necessary to use social media to expose messages on HBV. This will serve as an effective and best useful tool to not only creates awareness of the HBV among residents in Lagos State, it will also help to educate them on the precaution to prevent the virus and stop its spread in the state.

\section{Recommendations}

Based on the findings of this study, it is recommended as follows:

1. Operator and managers of health facilities in Lagos State should make use of the social media platforms as part of the potent channels of transmitting information on health issues such as Hepatitis B Virus.

2. The community health unit of public hospitals should conduct massive campaign on the powers and dangers of Hepatitis B Virus from time to time in order to make for commendable knowledge, attitude and practice of healthy life style among the populace.

3. Members of the public should frequently embark on voluntary Hepatitis B Virus test for timely ascertaining of their status and possible timely treatment in case of contraction.

4. Government should subsidise Hepatitis B Virus testing kits and treatment drugs for easy access by members of the public.

\section{REFERENCES}

[1]. Anaeto, S. G., Onobajo, O. S. \& Osifeso, J. B. (2008). Models and Theoriesnof Communication. Bowie: African Renaissance Books Inc.

[2]. Belo A.C. (2000). Prevalence of hepatitis B virus markers in surgeons in Lagos, Nigeria. East Afr Med J 2000;77:283-5.12.

[3]. Chaffey, D. and Ellis-Chadwick, F. (2012) Digital Marketing: Strategy, Implementation and Practice. 5th Edition, Pearson Education Limited, London.

[4]. Chaney, P. (2009). The digital handshake, seven proven strategies to grow your business using social media. New Jersey: John Wiley.

[5]. Ekwueme Anthony Chinedu and Okoro Ngozi, (2018). Analysis of the Use of Social Media Advertising Among Selected Online Businesses in Nigeria. International Journal of International Relations, Media and Mass Communication Studies Vol.4, No.2 pp.28-43, May 2018.

[6]. Emechebe GO, Emodi IJ, Ikefuna AN, Ilechukwu GC, Igwe WC, Ejiofor OS, et al. (2014). Hepatitis B virus infection in Nigeria - A review. Niger Med J 2009;50:18-22.

[7]. GAVI Alliance. (2014). Country Tailored Approach for Nigeria 2014-2018; 2014.

[8]. Gummesson E; Total Relationship Marketing, Marketing Management, relationship strategy and CRM Approaches for the Network Economy, Second Edition. Butterworth-Heinemann publications (2002)

[9]. Evans D. and Mikee J. (2010). The next generation of business engagement. Indianapolis-Indiana: Wiley Publishers

[10]. Janal D.S; Online Marketing Handbook, How to promote, advertise, and sell your products and services on the internet.(1998 Edition)John Wiley and Sons Inc.

[11]. Jefferies, M., Rauff, B., Rashid, H., Lam, T., \& Rafiq, S. (2018). Update on global epidemiology of viral hepatitis and preventive strategies. World journal of clinical cases, 6(13), 589-599. https://doi.org/10.12998/wjcc.v6.i13.589.

[12]. Mancinelli, R., Rosa, L., Cutone, A., Lepanto, M. S., Franchitto, A., Onori, P., Gaudio, E., \& Valenti, P. (2020). Viral Hepatitis and Iron Dysregulation: Molecular Pathways and the Role of Lactoferrin. Molecules (Basel, Switzerland), 25(8), 1997. https://doi.org/10.3390/molecules25081997

[13]. Musa B.M., Bussell S., Borodo M.M., Samaila A.A., Femi O.L., (2015). Prevalence of hepatitis B virus infection in Nigeria, 20002013: A systematic review and meta-analysis. Nigerian Journal of Clinical Practice, March-April 2015, Vol 18, Issue 2. Available at: https://www.ajol.info/index.php/njcp/article/download/113608/103 326

[14]. NOIPolls, (2019). Social Media Poll Report: Nigeria's Teledensity and Preferred Internet-Access Device, November 2019. Available at: $\quad$ https://noi-polls.com/wp-content/uploads/2019/11/SocialMedia-Poll-Report.pdf

[15]. NOIPolls, (2020). Condom Accessibility and Use in Nigeria, February 13, 2020. Available at: https://noi-polls.com/condompoll-result-release/

[16]. Nyekwere Endwell Onyinye, Kur Jude Terna, and Nyekwere Ogedi (2013), Awareness and Use of Social Media in Advertising: The Case of Facebook among Residents of Port Harcourt, Nigeria. African Research Journal: An International Multidisciplinary 
Journal, Ethiopia Vol. 7 (4), Serial No. 31, September, 2013:174194 ISSN 1994-9057 (Print) ISSN 2070--0083 (Online) DOI: http://dx.doi.org/10.4314/afrrev.7i4.11

[17]. Odhiambo Christine Adhiambo, (2012). "Social Media as a Tool of Marketing and Creating Brand Awareness." Vaasan Ammattikorkeakoulu University of Applied Sciences. Available at: https://www.theseus.fi/bitstream/handle/10024/44591/Christine.A. Odhiambo.pdf?sequence $=1$

[18]. Ola SO, Otegbayo JA, Odaibo GN, Olaleye OD, Olubuyide OL. (2002) Serum hepatitis C virus and hepatitis B surface antigenaemia in Nigerian patients with acute icteric hepatitis. West Afr J Med 2002;21:215-7.10.

[19]. Olufemi Lawore (2016). 22 Benefits of Social Media/Marketing for Nigerian Businesses. Pace Media. Available at: https://pacemediasite.wordpress.com/2016/05/09/22-importanceof-social-mediamarketing-for-nigerian-businesses/

[20]. Olusola Lanre, (2018). "The power of social media," The Guardian, 17 May, 2018. Available at https://guardian.ng/technology/the-power-of-social-media/

[21]. Ortiz-Ospina Esteban, (2019). "The rise of social media." Our World in Data, September 18, 2019. Available at: https://ourworldindata.org/rise-of-social-media

[22]. Osuala, E. C. (2007). Introduction to Research Methodology ( ${ }^{\text {rd }}$ ed.). Onitsha:African first Publishers Ltd.

[23]. Perz JF, Armstrong GL, Farrington LA, Hutin YJ, Bell BP. The contributions of hepatitis $\mathrm{B}$ virus and hepatitis $\mathrm{C}$ virus infections to cirrhosis and primary liver cancer worldwide. J Hepatol 2006; $45: 529-38$
[24]. Pries, L. 2008.'Transnational societal spaces. Which units of analysis, reference and measurement?', in L. Pries(ed.)Rethinking Transnationalism. The Meso-link of organisations, London/New York:Routledge.

[25]. Sadoh AE, Sadoh WE. Serological markers of hepatitis B infection in infants presenting for their first immunization. Niger J Paeadiatr 2013;40:248-53.14.

[26]. Schweitzer A, Horn J, Mikolajczyk RT, Krause G, Ott JJ. (2015). Estimations of worldwide prevalence of chronic hepatitis B virus infection: a systematic review of data published between 1965 and 2013. Lancet. 2015;386:1546-1555.

[27]. Senam, N. (2020). Essentials and Ethics of Communication Research . Uyo: Inela Ventures \& Publishers limited.

[28]. Shu-Chuan Chu, (2011). "Viral Advertising in Social Media," Journal of Interactive Advertising. Available at: https://www.researchgate.net/publication/271400004_Viral_Advert ising in Social Media

[29]. Statista (2020). Most popular social networks worldwide as of July 2020, ranked by number of active users (in millions). Available at: https://www.statista.com/statistics/272014/global-social-networksranked-by-number-of-users/

[30]. Yamane, Taro, (1967).Statistics, An Introductory Analysis, 2nd Ed., New York: Harper and Row.

[31]. World Health Organization. Eliminate Hepatitis: WHO. Available from: http://www.who.int/news-room/detail/27-07-2017-eliminatehepatitis-who [32]. World
https://worldpopulationreview.com/world-cities/lagos-pop 